\title{
ENHANCEMENT OF HEAT TRANSFER THROUGH A SUDDEN EXPANSION PIPE AIRFLOW USING PROPELLER SWIRL GENERATOR
}

\author{
A.E. Zohir and A.G.Gomaa** (alaa_sadegh@yahoo.com) \\ "Mechanical Eng. Dept., Tabbin Institute for Metallurgical Studies, Cairo, \\ ${ }^{* *}$ Mechanical Eng. Dept., Industrial education College, Helwan University
}

(Received April 1, 2012 Accepted April 29, 2012)

This investigation is aimed to study the heat transfer and pressure drop characteristics for turbulent airflow in a sudden expansion pipe $(d / D=0.72)$ equipped with propeller swirl generator with different blade angles. The investigation is performed for the Reynolds number ranging from 10,000 to 40,000 under a uniform heat flux condition. Four propeller fans of five blades with swirl angles, $\theta=15,30,45^{\circ}$ for upstream flow, and $45^{\circ}$ for downstream flow are inserted separately inside the test section. The swirl propeller fan is located at different locations inside the tested pipe, where $S$ $=10 \mathrm{H}, 20 \mathrm{H}$ and $40 \mathrm{H}$ for both upstream and downstream flows. The experimental results indicate that inserting the propeller upstream of the tube provides considerable improvement of the heat transfer rate up to $190 \%$ for all swirler angles with higher values obtained at $\theta=45^{\circ}$. Inserting the propeller downstream of the tube provides more improvement in heat transfer rate than inserting the propeller upstream of the tube at swirl angle of $\theta=45^{\circ}$, the heat transfer rate increased up to $225 \%$. The maximum enhancement efficiency $(\eta)$ for the downstream swirler is about $326 \%$ while it is about $213 \%$ for the upstream one. Correlations for relative mean Nusselt number and enhancement efficiency are presented for different fan locations, swirl angles and Reynolds numbers.

KEYWORDS: sudden expansion, swirl flow, heat transfer augmentation.

\section{INTRODUCTION}

Many researchers [1-6] have studied swirling flows in the past since such flows have practical applications in many combustion systems, such as industrial furnaces and gas turbine combustors. Swirling flows in both reacting and non-reacting conditions occur in a wide range of applications such as gas turbines, marine combustors, burners, chemical processing plants, rotary kilns and spray dryers. Swirling jets are used as a means of controlling flames in combustion chambers. The presence of swirl results in setting up of radial and axial pressure gradients, which in turn influence the flow fields. In case of strong swirl the adverse axial pressure gradient is sufficiently large to result in reverse flow along the axis and generating an internal circulation zone. The velocity components and turbulent stresses, which are main characteristics of swirling flows, have been investigated in the past for various configurations to understand the physical process both by experimental investigations and by numerical modeling, complementing each other. Heat transfer of enhancement techniques are applied in many engineering applications, such as heat exchangers, air conditioning, heat 
recovery processes, chemical reactor and refrigeration systems, to improve the heat transfer coefficient or thermal performance. The enhancement is directly related to the reductions of the size and cost of involved equipment. Heat transfer enhancement techniques are classified into two major groups, one is an active method which needs an external power source, another is a passive method which does not need any external power source. Among the techniques used in the passive methods, the use of swirling flow and sudden expansion, due to its low cost and high efficiency for improving heat transfer rate. The turbulent swirl flow through an abrupt axisymmetric expansion is a complex flow possessing several distinctly different flow regimes of recirculation and extremely high levels of turbulence. Heat transfer characteristics are often significantly altered by the nature of the flow separation and subsequent flow redevelopment. Swirl flow can be induced by different kinds of swirl generators such as injection, twisted tape, helical screw, vanes, etc. Some researchers examined twisted tape as a swirl generator. They studied the influence of length, twisted ratio, width, phase angle, and rod diameter on heat transfer and pressure drop.

\begin{tabular}{|cllll|}
\hline \multicolumn{3}{|c|}{ NOMENCLATURE } \\
$C_{p}$ & Fluid specific heat capacity, $\mathrm{J} / \mathrm{kg} \mathrm{K}$ & Greek Symbols \\
$D$ & Upstream pipe diameter, $\mathrm{m}$ & $\theta$ & Swirl generator vane angle, ${ }^{\circ}$ \\
$D$ & Test section Pipe diameter, $\mathrm{m}$ & $\eta$ & Enhancement efficiency $\left(N u_{m} / N u_{f \cdot d}\right)$ \\
$H$ & Heat transfer coefficient, $\mathrm{W} / \mathrm{m}^{2} \mathrm{~K}$ & $\mu$ & Viscosity of the fluid, $\mathrm{N} / \mathrm{m}^{2}$ \\
$H$ & Step height, $H=0.5(D-d), \mathrm{m}$ & $\rho$ & Density, $\mathrm{kg} / \mathrm{m}^{3}$ \\
$K$ & Fluid thermal conductivity, W/m K & Subscripts \\
$L$ & Test section pipe length, $\mathrm{m}$ & $b$ & Bulk \\
$\dot{m}$ & Mass flow rate, $\mathrm{kg} / \mathrm{s}$ & $e$ & Exit \\
$N$ & Blades number & $f d$ & Fully developed \\
$N u$ & Nusselt number & $h$ & Heated \\
$\Delta P$ & Pressure drop, Pa & $i$ & Inlet \\
$q$ & Heat flux, W/m ${ }^{2}$ & $m$ & Mean \\
$Q$ & Heat transfer rate, $\mathrm{W}$ & $m r$ & Relative mean \\
$R e$ & Reynolds number & $o$ & $(d / D=1)$ without swirl \\
$T$ & Temperature, ${ }^{\circ} \mathrm{C}$ & $r$ & Relative \\
$X$ & Distance, $\mathrm{m}$ & $s$ & Surface \\
$S$ & Swirler position, $\mathrm{m}$ & $x$ & Local \\
\hline
\end{tabular}

Yildiz et al. [7] found increasing in the heat transfer rate by up to $100 \%$ by using stripes twisted tape. Chang et al. [8] found an increase in heat transfer coefficient of 1.28:2.4 by using broken twisted tape. Eiamsa-ard and Promvonge [9] used serrated twisted tape to produce continuous swirl flow in constant heat fluxed tube to study its effect on heat transfer and pressure loss. The heat transfer rate was increased by up to $72.2 \%$ and $27 \%$ relative to the plain tube and the twisted tape (TT) inserted tube, respectively. The use of the serrated twisted tape (STT) leads to higher heat transfer rate and friction factor than that of the TT for all cases. The thermal performance factor of the STT tube, under constant pumping power, was above unity, which indicating that STT is advantageous over the TT tube or the plain tube. Wongcharee and Eiamsa-ard [10] performed a comparison between using of the typical twisted tape (TT) and 
alternate clockwise and counter clockwise twisted tape (TA) on the thermo hydraulic characteristics. They tested three different twisted ratios. They obtained that Nusselt number, friction factor, and thermal performance factor associated by TA are higher than those associated by TT. Among the tapes examined, the tape with the smallest twist ratio was found to be the most efficient for heat transfer enhancement.

Gül and Evin [11] used short length helical screw to enhance the heat transfer inside pipe. They achieved a net energy gain up to $20 \%$ depending upon the Reynolds number, tape angle and channels number. A propeller vane was also used to produce swirling flow in pipe. Zaherzadeh and Jagadish [12] and Sarac and Bali [13] studied the influence of different propeller vane parameters (blade width, diameter, blades number, vane angle and swirl generator) on the heat transfer and pressure drop inside pipe. They found that Nusselt number and pressure drop increased with blades number increasing. In addition, Nusselt number and pressure drop increased with vane angle decreasing. A continuous swirling flow induced by more than one propeller vane, inserted inside pipe at equal interval distance, was studied by [14-18]. They examined the effect of different parameters like (vane angle, number of swirl generator, blades number, etc) on the heat transfer rate and pressure drop. They found that, using more than one propeller vane gave results better than using full-length twisted strips. They also found that Nusselt number and efficiency increased with vane angle decreasing, except for Eiamsa-ard et al. [18] who found that the efficiency and the heat transfer increased with vane angle increase. Numerical studies for turbulent swirling flow characteristic through sudden pipe expansion were done by Vanierschot and Bulck [19], who found that the reattachment length for swirling flow through sudden expansion depends on the swirl number, expansion ratio and the reattachment length at zero swirls. Dellenback et al. [20] and [21] studied the effect of swirling motion created by injectors inside sudden pipe expansion on the velocity and heat transfer. They found that as swirl number increased from zero to 1.2, the peak local Nusselt number increased from 3 to 9.5 times larger than fully developed value and its location moved towards the inlet. Zohir et al [22] compared the effect of propeller vane and spiral spring on the heat transfer and pressure drop through sudden pipe expansion. They used air, with Reynolds number ranged from 7500 to 18,500 as working fluid. They tested different locations for the propeller vane and different spring pitch ratios. They found that using of a propeller vane improved the heat transfer to 1.69 times over the plane tube (sudden expansion pipe) with three times increasing in the pressure drop. While using of spring increased the heat transfer to 1.37 times over the plane tube with 1.5 increasing in the pressure drop. Khalil et al [23] and Zohir [27] studied the effect of inserting a propeller vane (swirl generator) inside sudden expansion pipe on the heat transfer and pressure drop. They used air with different Reynolds number as a working fluid. They tested the effect of different vane angles, sudden expansion ratio, Reynolds number $(9,000$ to 41,000$)$, and swirler locations on the enhancement efficiency for reaching the optimum conditions. A maximum enhancement efficiency of $405 \%$ was obtained at Reynolds number of 9746 , vane angle $=60^{\circ}$ and low sudden expansion ratio of 0.32 .

In order to investigate the effects of swirling airflow by inserted propeller fan with different angles used as turbulators, on the heat transfer and pressure drop through sudden expansion pipes, an experimental facility was designed and constructed in the 
present study. In this facility, the swirl generator with different swirl angles, $(\theta=$ $\left.15: 45^{\circ}\right)$, was located at three different locations $(S=10,20$ and $40 H)$ upstream and downstream of the sudden expansion pipe.

\section{TEST RIG AND INSTRUMENTATION}

\subsection{Layout of the Test Rig}

An experimental facility is designed and constructed to investigate the heat transfer characteristics of the swirling fully developed turbulent flow through sudden pipe expansion $(d / D=0.72)$. Four propeller fans of five blades with swirl angle, $\theta=15,30$, $45^{\circ}$ for upstream flow, and $45^{\circ}$ for downstream flow were inserted separately inside the test section. The swirl propeller fan was located at different locations inside the tested pipe, $S=10 H, 20 H$ and $40 H$ for both upstream and downstream flows. The test rig consists of an air supply unit (7 Hp air blower of equipped with air flow control unit), an orifice meter, settling chamber, upstream calming tube, the test section and swirling generators (propeller fan). The details of the test rig are shown in Fig 1.

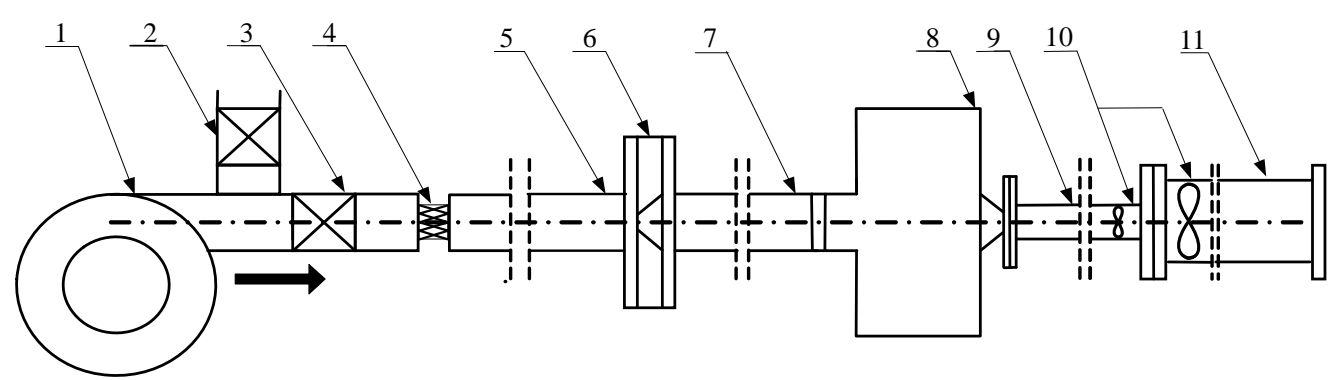

1.Air blower

2.By-pass valve

3.Flow control valve

4.Flexible connection

5.Upstream tube of orifice

6.Orifice meter
7.Downstream tube of orifice

8.Settling chamber $(\mathrm{D}=500 \mathrm{~mm})$

9.Upstream calming tube $(\mathrm{d}=59 \mathrm{~mm})$

10. Propeller fan with different angles

11. Test section $(\mathrm{D}=82 \mathrm{~mm})$

\section{Figure 1: Layout of the turbulent swirling flow test rig}

\subsection{Test Section}

The test section, as shown in Fig 2a, consists mainly of a main pipe, heaters, insulating materials and swirl generators. The heat losses from the test section tube to the atmosphere are minimized by insulating the tube. The test section was covered with eleven heating elements each of them having $28.5 \mathrm{~m}$ length and $124 \Omega$ electric resistance. Heating elements were made of nickel chromium wire which has a resistance of $4.35 \Omega / \mathrm{m}$ and a diameter of $0.6 \mathrm{~mm}$. A uniform heat flux of $1027 \mathrm{~W} / \mathrm{m}^{2}$ was applied along the test section pipe. Two voltage regulators were used to supply the heaters with the required power. Sheets of aluminum of $0.2 \mathrm{~mm}$ thickness were wound below and above the heater wires to distribute the heat uniformly. Then a layer of glass 
wool insulation of $50 \mathrm{~mm}$ thickness was employed to cover the pipe. The total heat loss from the heaters to the atmosphere was calculated and it was found to be less than $6 \%$ of the total heat input. Main tube of test section was made of stainless steel, (low thermal conductivity $13.4 \mathrm{~W} / \mathrm{m} \mathrm{K}$ ), of $82 \mathrm{~mm}$ inner diameter, $2 \mathrm{~m}$ length and $2.5 \mathrm{~mm}$ thickness.

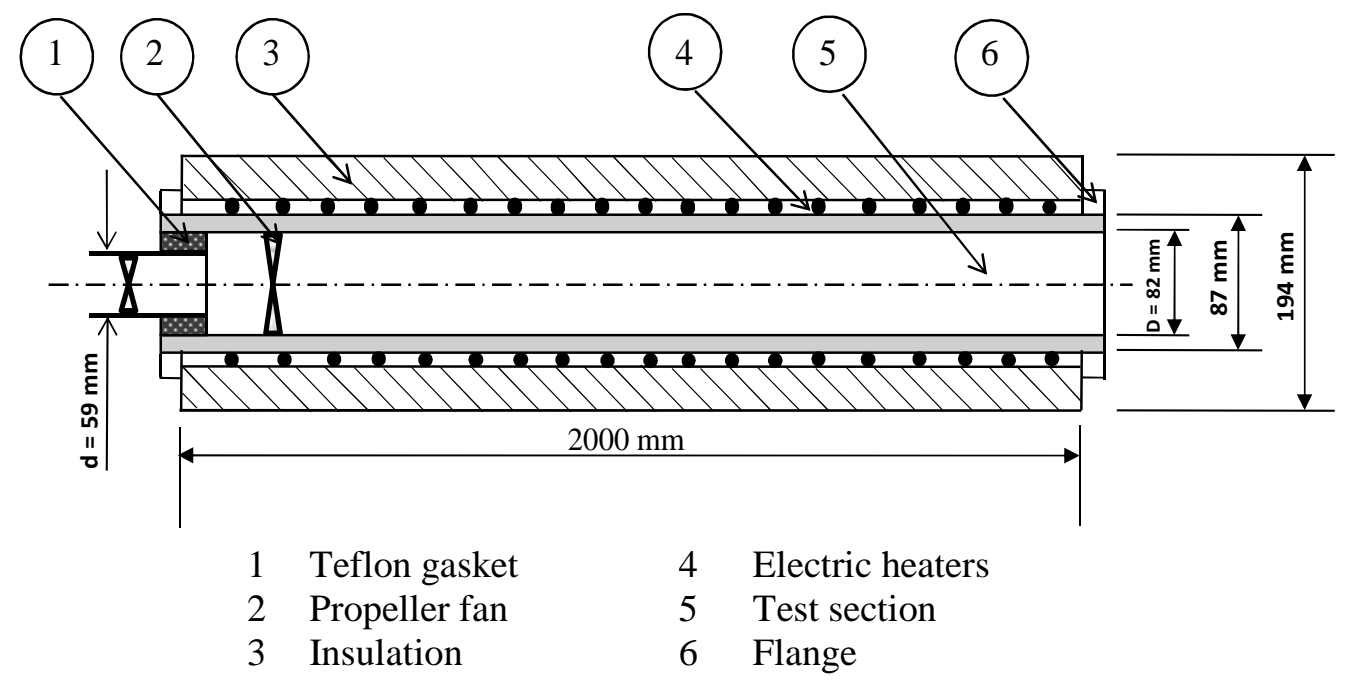

Figure 2a: The test section details (Dimensions in $\mathbf{m m}$ )

The convection heat losses are the losses of heat through the insulation to the atmosphere and the axial conduction losses due to tube thickness. The major heat losses are assumed to be through the insulation only with neglecting the other losses as concluded by Baughn et al. [24] and Incropera and Dewitt [25]. The surface temperatures have been measured by 49 thermocouples of K-type (having about 0.3 $\mathrm{mm}$ wire diameter). The junctions of the thermocouples were soft soldered to grooves milled in the surface parallel to the tube axis. The junctions of the thermocouples are embedded in holes of $2 \mathrm{~mm}$ diameter and $2 \mathrm{~mm}$ depth onto the tube surface. The thermocouples were located at different axial positions along the tube length as shown in Fig 2b. The thermocouples were not uniformly spaced and the spacing ranged from $5 \mathrm{~mm}$ near the abrupt expansion corner to $200 \mathrm{~mm}$ near the exit of the large diameter. Most of the axially distributed thermocouples were at the top mid-plane of the tube. However, five additional thermocouples placed at other angular locations were used to check the symmetry of the heat transfer to the flow. The propeller fan was located at different positions freely inside the test section.

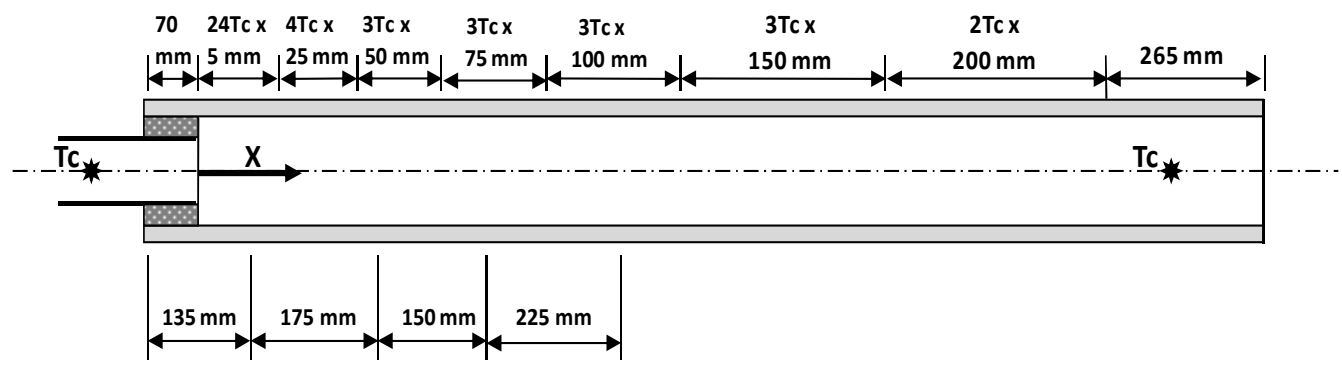




\section{EXPERIMENTAL PROCEDURE}

An experimental program was carried out to study the influence of swirl angle, for upstream and downstream swirling flows, on the heat transfer and pressure losses of turbulent flow inside circular tubes. The considered cases are for values of Reynolds numbers of $10000,15000,18900,30000$, and 40000 which corresponding to mass flow rates of $0.01231,0.01792,0.02625,0.03463$, and $0.05326 \mathrm{~kg} / \mathrm{s}$ respectively. The propeller fans, of 5 blades and $\theta=15^{\circ}, 30^{\circ}, 45^{\circ}$ for upstream swirling while $\theta=45^{\circ}$ for downstream swirling, were rotated freely by the airflow and located at six different locations $(S / H=10,20$ and 40$)$ with respect to the location of the sudden expansion. The net heat transfer by convection to air can be calculated from Eq. (1). The local mean bulk temperature of air in each segment of the test section is calculated from Eq. (2). The properties of air are determined at mean bulk temperature. The heat lost $Q_{\text {loss }}$ has been measured using Fourier's low of radial heat conduction by measuring the outer surface temperatures of the insulation at the corresponding points where the tube wall surface temperature were measured. The heat loss was found to vary between $5 \%$ and 6\% of heater input power. In the analysis $Q_{l o s s}$ was assumed to be $6 \%$.

$Q_{\text {net }}=\left(Q-Q_{\text {loss }}\right)=\dot{m} C_{p}\left(T_{b e}-T_{b i}\right)$

$T_{b x}=T_{b i}+\dot{q}_{o} \pi D L_{x} / \dot{m} C_{p}$

where $\dot{q}_{o}$ is the uniform heat flux and can be calculated from

$\dot{q}_{o}=$ const. $=Q_{n e t} / \pi D L_{h}$

The local and mean heat transfer coefficients are determined from Eqs. (4) and (5). The local and mean Nusselt number can be calculated, respectively, from Eq. (6).

$$
\begin{aligned}
& h_{x}=\dot{q}_{o} /\left(T_{s x}-T_{b x}\right) \\
& h_{m}=\frac{1}{L} \int_{0}^{L_{b}} h_{x} d L_{x} \\
& N u_{x}=h_{x} D / k \\
& N u_{m}=h_{m} D / k
\end{aligned}
$$

The enhancement efficiency $\eta$ is defined as the ratio of the heat transfer coefficient for the inserted tube $h_{m}$ to that for the plain tube $h_{o}$ at the same pumping power, according to ref [4, 6 and 23].

$$
\eta=\left[h_{m} / h_{o}\right]
$$

A more precise method of estimating uncertainty in experimental results has been presented by Kline and McClintock, which is described in Holman [26]. The method is based on careful specification of the uncertainties in the various primary 
experimental measurements, suppose that the result dependant variable $(\mathrm{R})$ is a given function of the independent variables $x_{1}, x_{2}, x_{3}, \ldots \ldots \ldots \ldots ., x_{n}$. Thus: $R=R\left(x_{1}, x_{2}, x_{3}\right.$, $\left.\ldots \ldots \ldots \ldots, x_{n}\right)$. Let $u_{R}$ is the uncertainty in the result and $\mathrm{u}_{1}, \mathrm{u}_{2}, \mathrm{u}_{3}, \ldots \ldots, \mathrm{u}_{\mathrm{n}}$ are the uncertainties in the independent variables. The uncertainty in the results is given by the following equation:

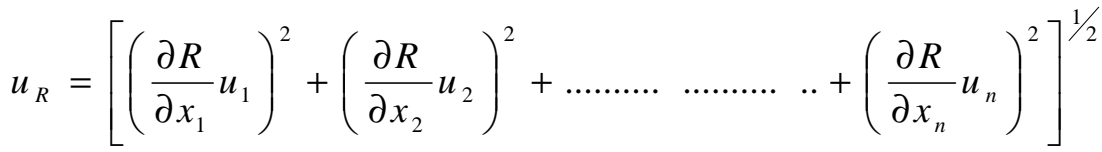

Table 1 summarizes the calculated values of uncertainty of the measured quantities.

Table 1, the calculated uncirtainty values of the measured quantities

\begin{tabular}{|l|l|l|}
\hline Parameter & Absolute Uncertainty & Relative \\
\hline Mass flow rate & & $\pm 1.1 \%$ \\
\hline Reynolds number & & $\pm 1.1 \%$ \\
\hline Heat supplied & & $\pm 1.4 \%$ \\
\hline Bulk mean temperature & $\pm 0.75^{\circ} \mathrm{C}$ & \\
\hline Surface temperature & $\pm 1.0^{\circ} \mathrm{C}$ & \\
\hline Heat transfer & & $\pm 4.8 \%$ \\
\hline Nusselt number & & $\pm 4.8 \%$ \\
\hline
\end{tabular}

\section{RESULTS AND DISCUSSION}

\subsection{Heat transfer characteristics}

The fully developed local Nusselt number results of smooth pipe $(d / D=1)$ are compared with the results of Dittus-Boelter, which is described in Incropera and Dewitt [25] as shown in figure 3. A good agreement between the experimental results and results of Dittus-Boelter equation was achieved with deviation $\pm 6 \%$. The experimental results of the local Nusselt number, of non-swirl, distribution along the pipe length for a sudden expansion pipe at different Reynolds numbers are drawn in figure 4. The longitudinal distance $(X)$ is normalized by the step height $(H=0.5(D-$ d)). The results indicate a gradual increase in local Nusselt number at the inlet of the sudden expansion pipe $(\mathrm{X} / \mathrm{H}=0)$ and an increase to a peak value at the reattachment point $(\mathrm{X} / \mathrm{H} \approx 10)$. The figure shows that the peak decreases gradually to a nearly constant value at $X / H \geq 40$. A strong recirculation zone is formed just downstream of the sudden expansion and a reversed flow takes place in this region and would be extended in radial direction. As the Reynolds number increases, separation and recirculation zones are formed due to the adverse pressure gradient caused by the sudden expansion, then the boundary layers are destroyed, and as a result, the Nusselt number increases. 


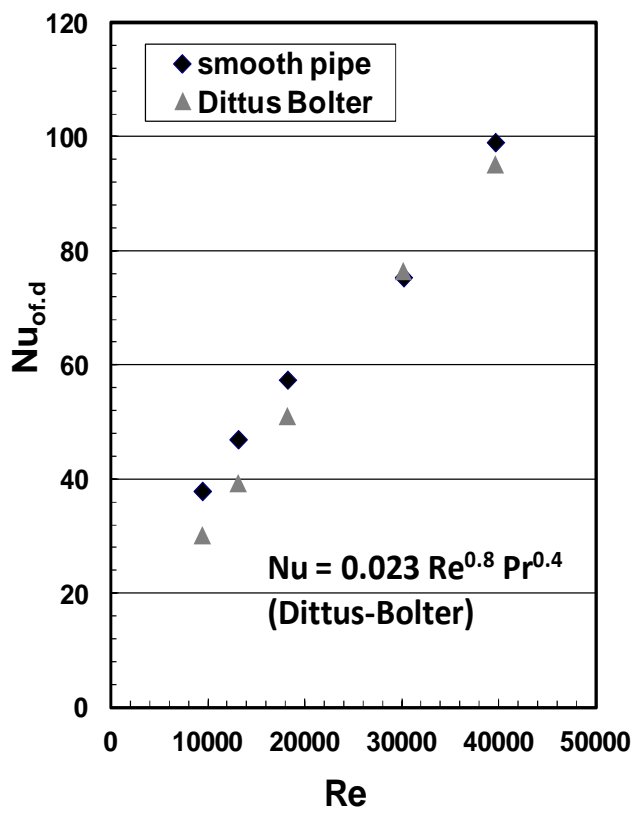

Figure 3: Comparison of Nusselt number for flow without swirl and that of Dittus-Bolter Equation, (d/D = 1)

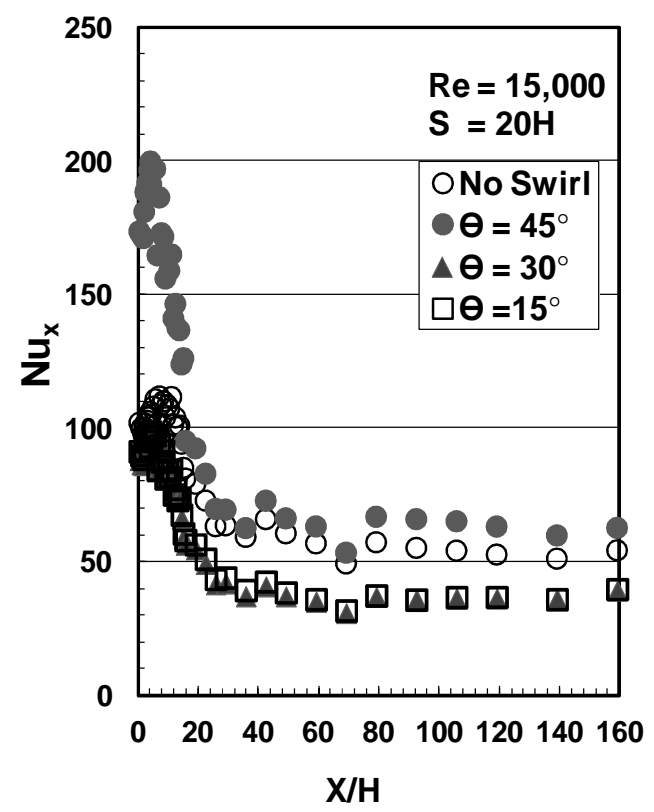

Figure 5: Local Nusselt number variation versus dimensionless tube length for different swirl angles

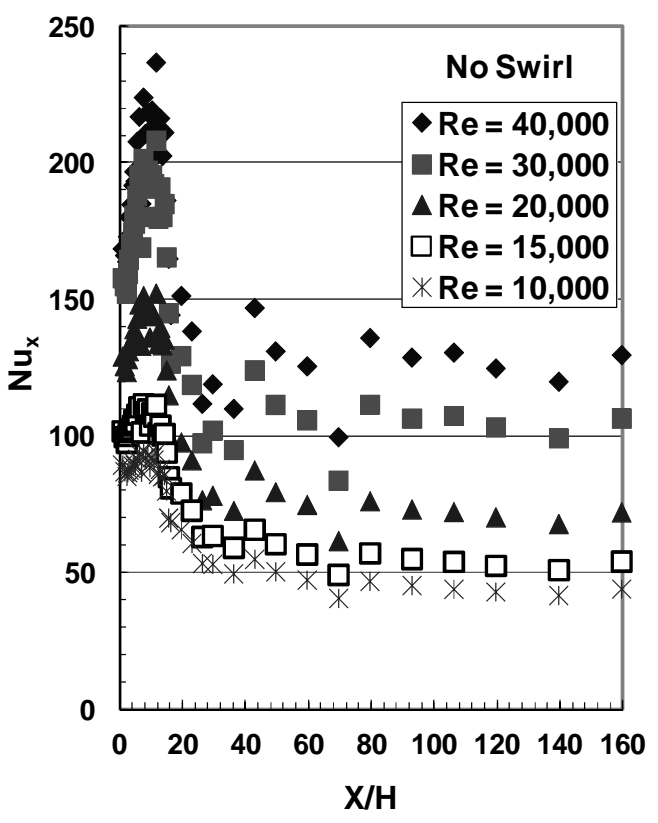

Figure 4: Variation of local Nusselt number for flow without swirl versus dimensionless tube length

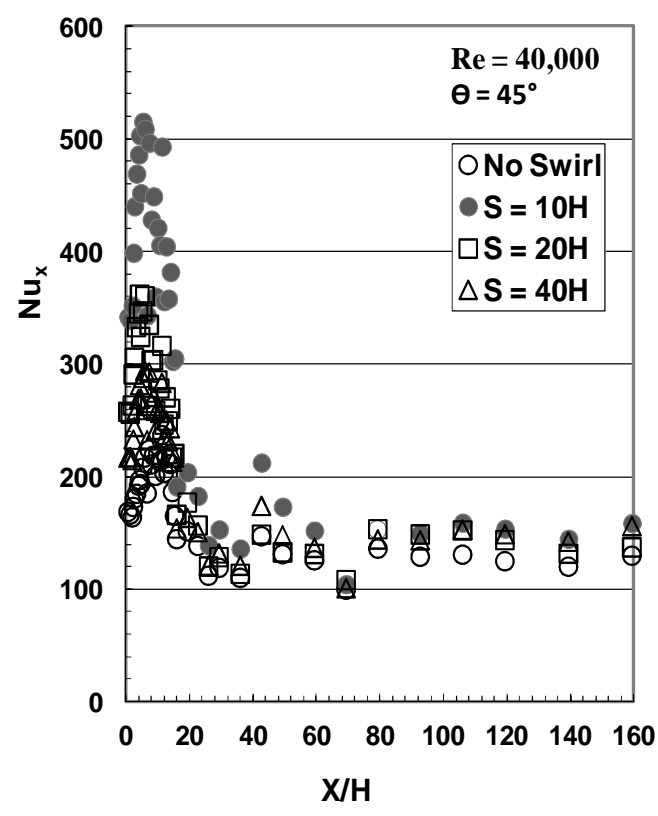

Figure 6: Local Nusselt number variation versus dimensionless tube length for different swirler locations 
Downstream the impingement region, the thermal boundary layer grows, and Nusselt number generally decreases to a very low value to settle down to the value for a fully developed pipe flow. The effects of the Reynolds number on Nusselt number around the impingement region on the pipe are substantial and these effects decrease slowly to the pipe exit.

Variations of local Nusselt number against dimensionless tube length $(X / H)$, at different swirl angles and swirler locations for upstream swirling flows through the sudden expansion pipe, are shown in Figs. 5 and 6. The results, figure 5, show that the local Nusselt number distribution gives a nearly same trend for sudden expansion pipe with and without swirl with improvements in heat transfer rate obtained for swirler angle $45^{\circ}$, while a reduction obtained at swirler angle $30^{\circ}$ and $15^{\circ}$. The local Nusselt number increases suddenly to a maximum value near the reattachment point and then decreases to a fully develop value. With swirl generator, of different swirler angles, inserted upstream the sudden expansion, the position of the maximum local Nusselt number moves towards the edge of sudden expansion $(X / H$ is close to 10). This behavior is due to the reduction in the length of the recirculation zone due to swirling flow induced by the swirl generator. Then, it decreases slowly to a fully developed value. As swirler angle decreases, lower heat transfer rates will be obtained. The influence of swirler location on local Nusselt number is shown in figure 6 . The results show that, as the swirler becomes very close to the sudden expansion inlet $(10 \mathrm{H})$, more enhancements in local Nusselt number will be obtained with upstream swirling.

Variations of local Nusselt number against dimensionless tube length $(X / H)$, at different swirler locations, for both upstream and downstream swirling flows through the sudden expansion pipe $\left(\Theta=45^{\circ}\right.$ and Reynolds number $\left.=20,000\right)$, are shown in figures 7 and 8 . The Nusselt number distribution gives a nearly same trend for plain sudden expansion pipe. The local Nusselt number increases suddenly to a maximum value near the reattachment point and then decreases to a fully develop value.

The influence of swirl angle $\left(\Theta=15^{\circ}: 45^{\circ}\right)$ on the heat transfer rate at different Reynolds numbers, for upstream swirling flows, is shown in figures 9 and 10 . Reynolds number was varied from 10000 to 40000, and swirl generator location varied from $S / H=10$ to 40 . The figures show that, as swirl generator angle increases, the mean Nusselt number increases due to the increasing in the intense of the recirculation zone and the increasing of the rotational flow. As Reynolds number increases, the mean Nusselt number increases due to the increasing in the length of the recirculation zone and the increasing of the tangential flow. The heat transfer rates were significantly affected with Reynolds number, swirl angle and swirl generator location with more enhancements for downstream swirling. More heat transfer enhancements can be obtained for small $S / H$.

Figures 11 and 12 show the relative mean Nusselt number $\mathrm{Nu}_{\mathrm{mr}},\left(\mathrm{Nu}_{\mathrm{m}}\right.$ of swirl flow for $\mathrm{d} / \mathrm{D}=0.72$ is normalized by $\mathrm{Nu}_{\mathrm{mo}}$ of steady flow in a straight pipe for $\mathrm{d} / \mathrm{D}=1$ ), versus Reynolds number for different swirler locations, $\mathrm{S}$, at different swirl angles $\Theta=15^{\circ}: 45^{\circ}$. At high swirl angle $\left(\Theta=45^{\circ}\right)$, figure 11 shows that for all swirl locations (S), the value of $N u_{m r}$ are above unity, which mean that insertion of swirl generator upstream or downstream the sudden expansion pipe increases the heat transfer rate. 


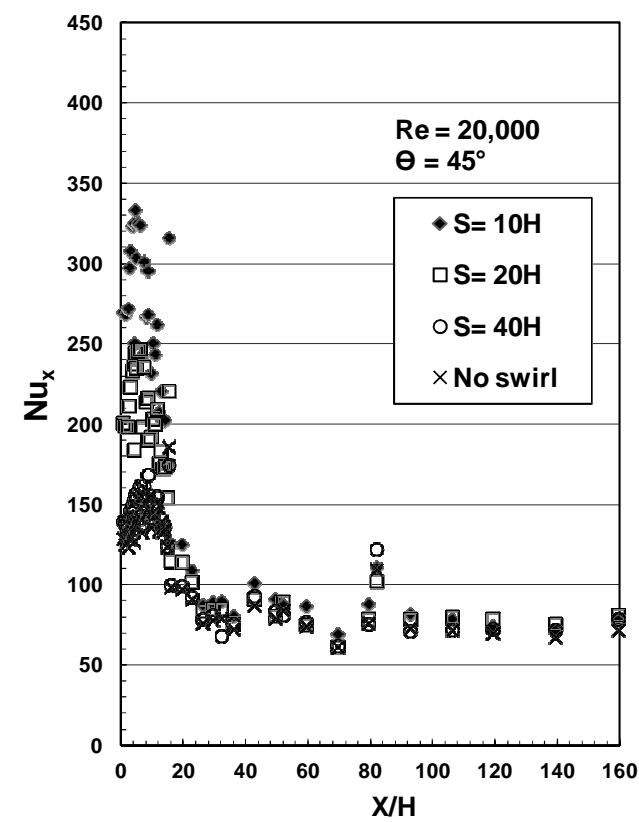

Fig 7: Local Nusselt number variation versus dimensionless tube length for upstream swirler

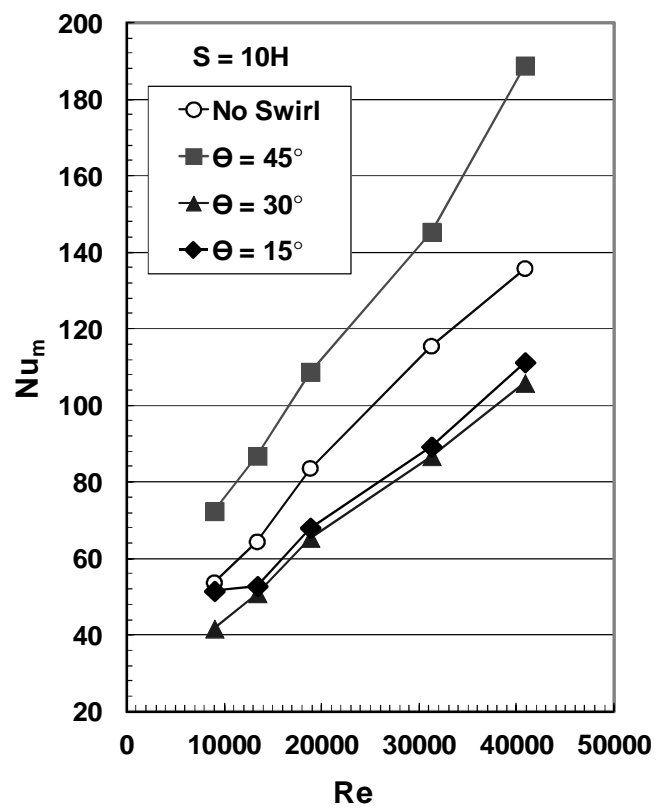

Figure 9: Mean Nusselt number variation versus Reynolds number for different swirl angles $\mathrm{S}=10 \mathrm{H}$

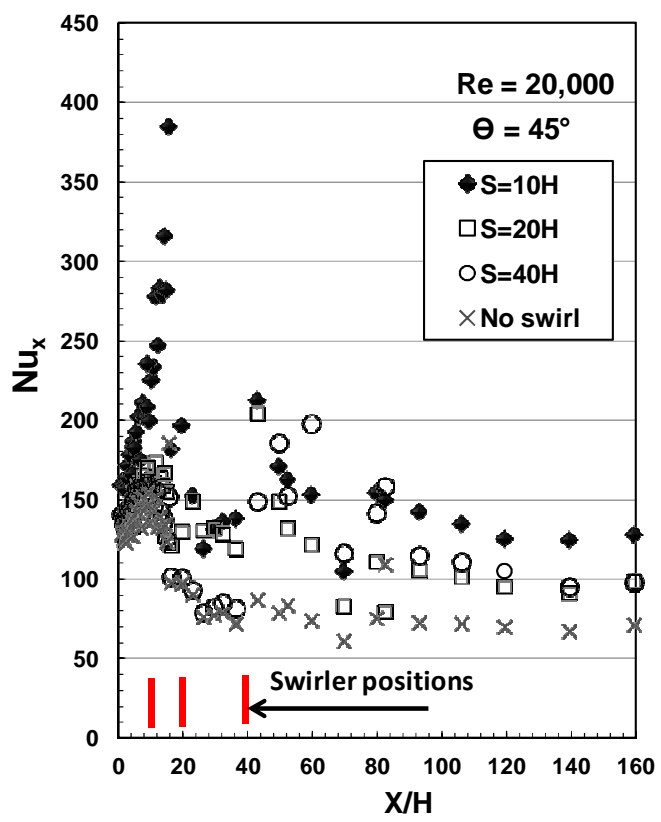

Fig 8: Local Nusselt number variation versus dimensionless tube length for downstream swirler

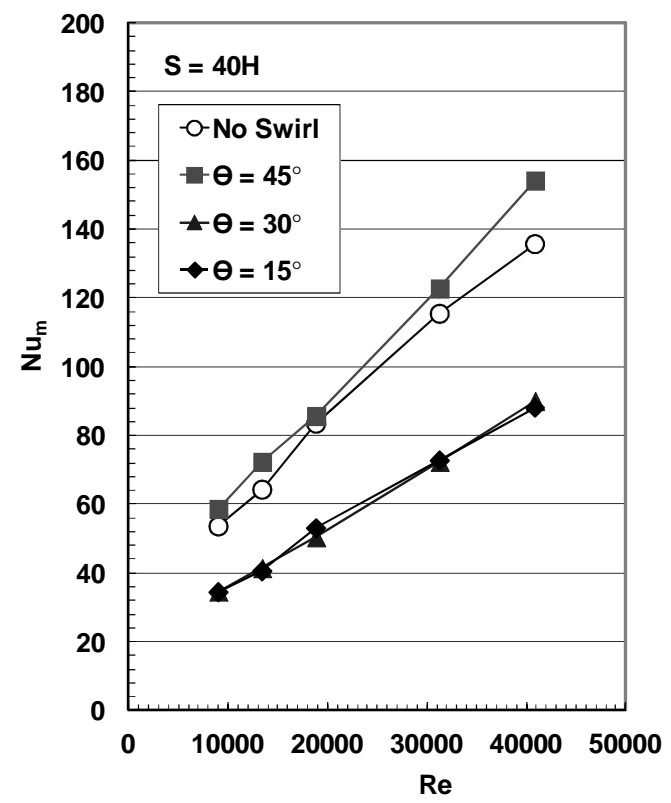

Figure 10: Mean Nusselt number variation versus Reynolds number for different swirl angles $\mathrm{S}=40 \mathrm{H}$ 
For upstream swirling, the experimental results indicate that inserting the propeller upstream of the tube provides considerable improvement of the heat transfer rate up to $190 \%$ for all swirler angles with higher values obtained at $\Theta=45^{\circ}$. While, inserting the propeller downstream of the tube provides considerable improvement of the heat transfer rate with about $20 \%$ higher than inserting the propeller upstream the tube at swirl angle of $\Theta=45^{\circ}$, figure 11. At low swirl angle $\left(\Theta=15^{\circ}\right)$, figure 12 shows that the improvement in $N u_{m r}$ will occur only when the swirler is located very close to the inlet of the sudden expansion pipe $(S=10 \mathrm{H})$. The relative mean Nusselt number $N u_{m r}$ increases or decreases depending on Reynolds number value, swirler angle and swirler location.

\subsection{Pressure drop}

As shown in figure 13 and figure 14, the pressure drop increases as Reynolds number or swirl angle increases due to the increasing in the flow paths and swirling flow density. The effect of Reynolds number on the pressure drop is small at low flow rates. In addition, the influence of swirl angle on the pressure drop is small at small swirl angles. Swirler position has significant effect on the pressure drop. The pressure drop increases when the swirler is close to the edge of sudden expansion for both upstream and downstream swirler. In addition, the pressure drop for upstream swirler is higher than that for swirler located downstream the sudden expansion. The effect of swirl generator location on the pressure drop is small at low values of Reynolds number. The figures show also, that the maximum pressure drop is $979 \mathrm{~N} / \mathrm{m}^{2}$ at $\operatorname{Re}=40,000, \Theta=$ $45^{\circ}$ and $S=10 H$ for the upstream swirler.

\subsection{Heat transfer enhancement efficiency}

The heat transfer enhancement efficiency $(\eta)$ is defined as the ratio of the heat transfer coefficient, for sudden expansion pipe equipped with swirl generator, to the corresponding fully developed heat transfer coefficient without swirl in plain tube at the same pumping power [9 and 10]. The present results showed that the propeller swirl generator increases the heat transfer rate on the expense of pressure drop. Therefore, the heat transfer enhancement efficiency $\left(\eta=N u_{m} / N u_{f . d}\right)$ is used to show whether, in terms of energy saving, the inserting of swirl generator through sudden pipe expansion is cost effective or not. Figure 15 and 16 show the effect of swirling angle through sudden expansion pipe on the enhancement efficiency for upstream and downstream swirlers. The figures show that the enhancement in $(\eta)$ is generally greater than unity for $\Theta>15$. The maximum enhancement efficiency $(\eta)$ for the downstream swirler is about $326 \%$ while it is about $213 \%$ for the upstream one. For small swirl angle, figure $16, \Theta=15$, there are little enhancements in $\eta$ up to $50 \%$. This means that using of a propeller swirl generator after or before a sudden expansion of a pipe increases $\eta$. The figures also show that the enhancement efficiency $(\eta)$ decreased slightly with increasing the Reynolds number. As Reynolds number increases, $N u_{m r}$ decreases while the pressure drop increases. The results show that; the enhancement efficiency $(\eta)$ increases as the swirler is close to the edge of the sudden expansion. 


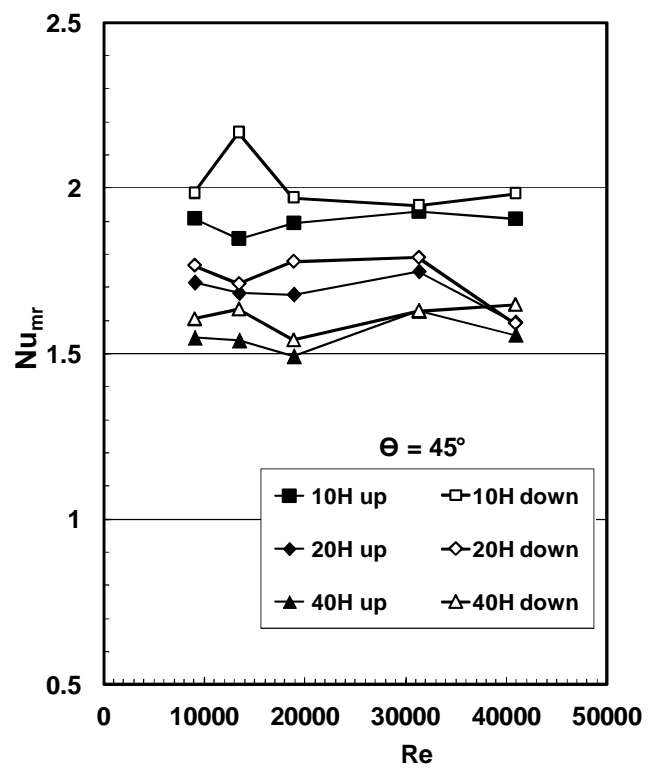

Figure 11: Relative mean Nusselt number variation versus Reynolds number for different swirler locations $\Theta=45^{\circ}$

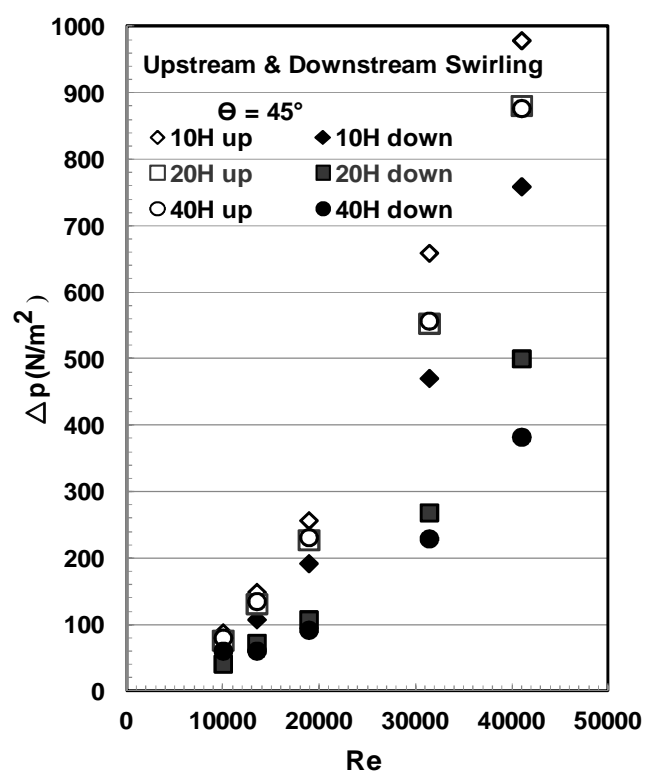

Figure 13: Pressure drop variation versus Reynolds number for upstream and downstream swirler at different positions

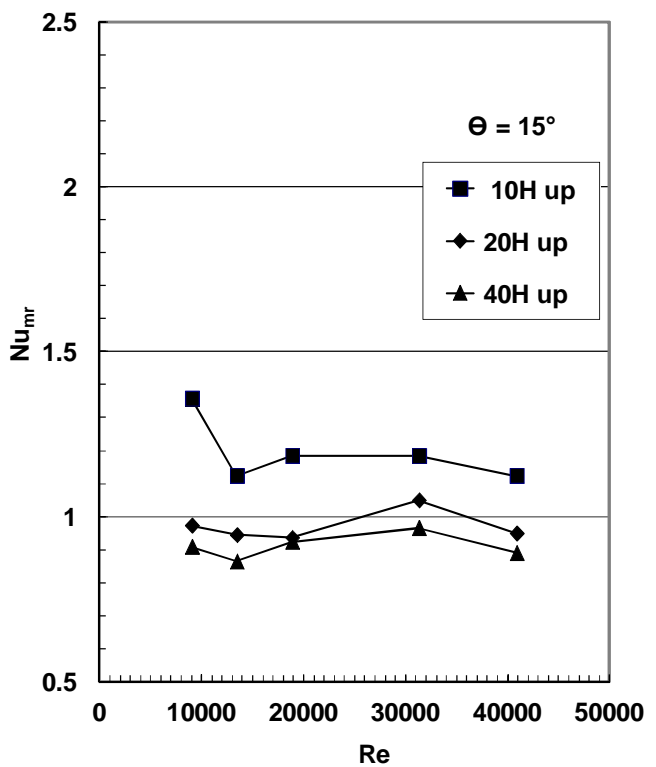

Figure 12: Relative mean Nusselt number variation versus Reynolds number for different swirler locations $\Theta=15^{\circ}$

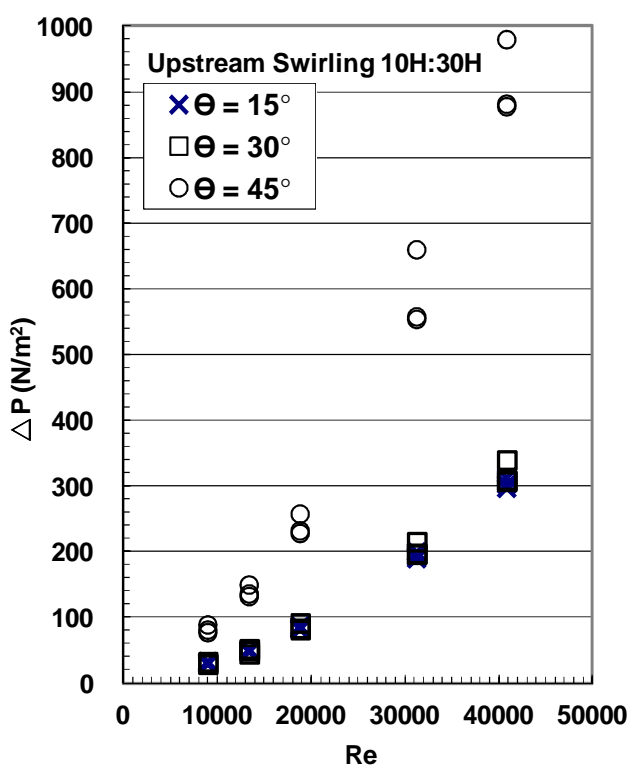

Figure 14: Pressure drop variation versus Reynolds number for upstream swirler with different angles 


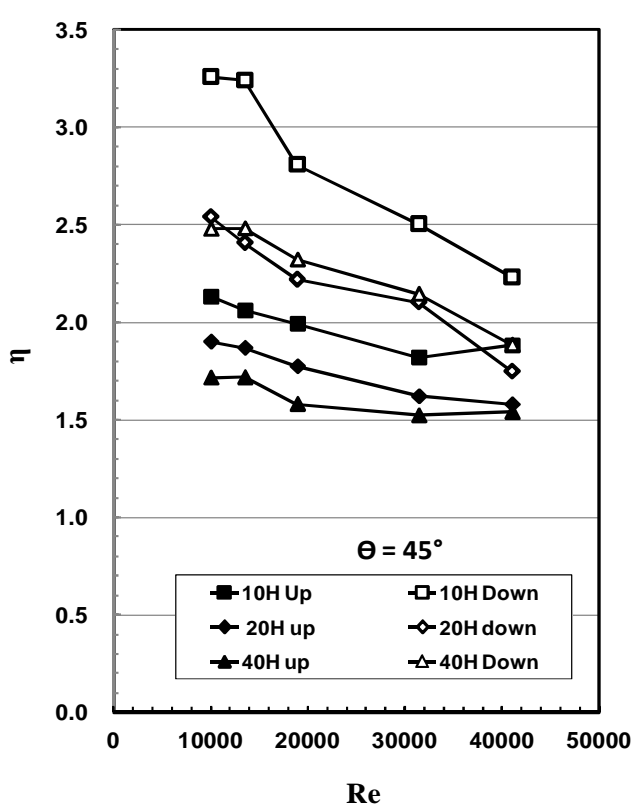

Figure 15: Enhancement efficiency variation versus Reynolds number for different swirl locations, $\Theta=45^{\circ}$

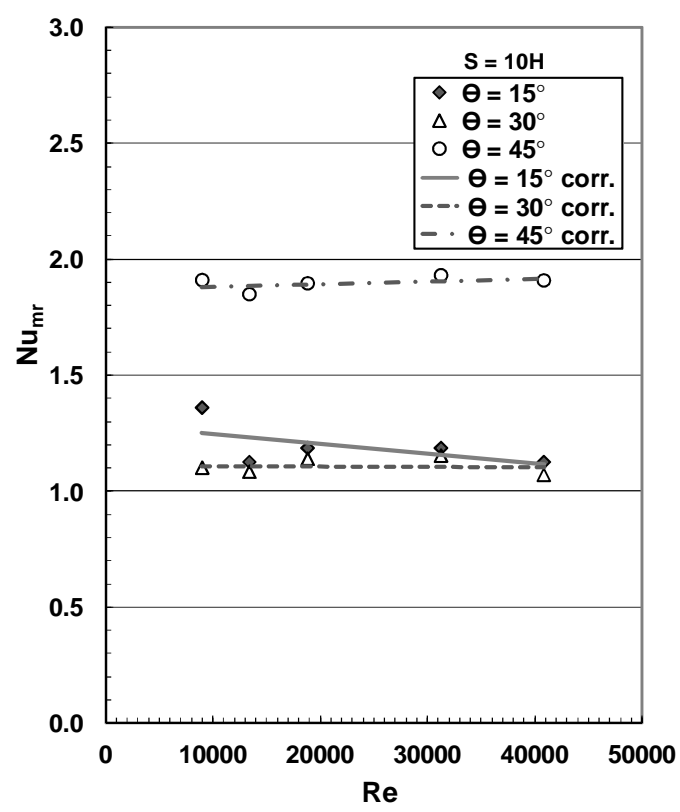

Figure 17: Results correlation of relative mean Nusselt number versus Revnolds number

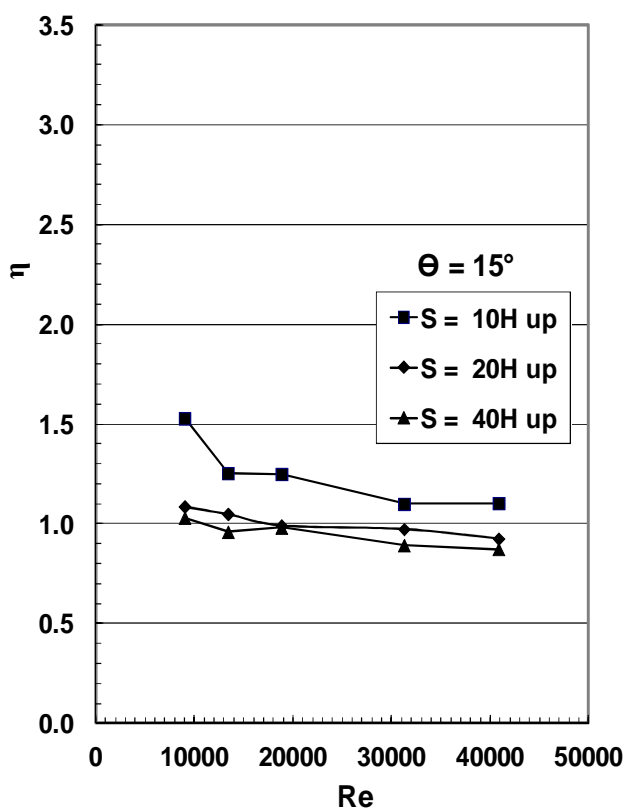

Figure 16: Enhancement efficiency variation versus Reynolds number for different swirl locations, $\Theta=15^{\circ}$

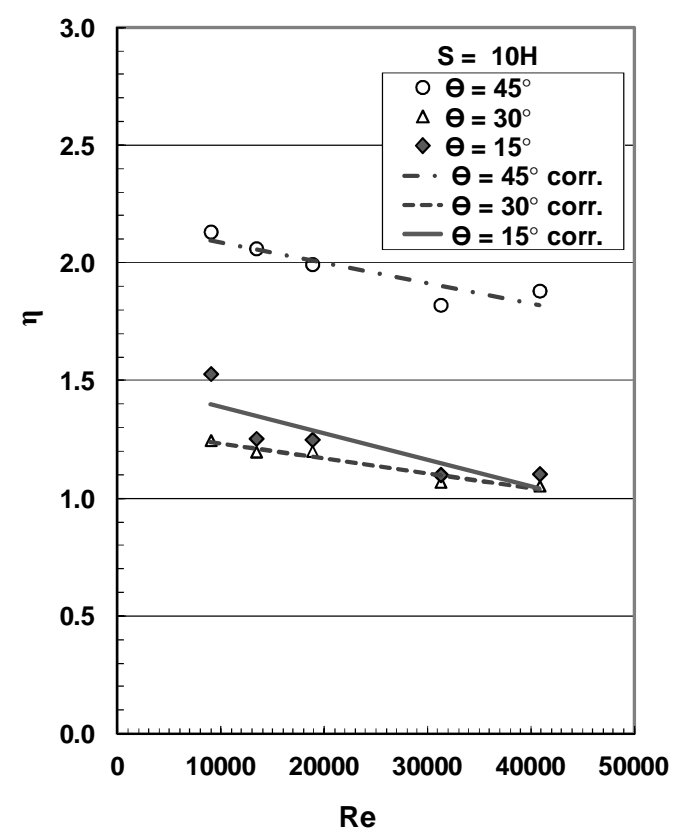

Figure 18: Results Correlation of enhancement efficiency versus Revnolds number 


\subsection{Correlations of Results}

Correlations for the turbulent swirling flow with different values of swirler location, upstream the sudden expansion, (for predicting the pressure drop, the relative Nusselt number and enhancement efficiency), were derived in the following equations. The pressure drop results shown in figures 13 and 14 are correlated in form of

$\Delta \mathrm{P}=\mathrm{f}(\mathrm{Re}, \Theta, \mathrm{S})$. The correlation and its constants are;

$$
\Delta P=a \operatorname{Re}+b(\tan \theta)+c S+d
$$

Where $\mathrm{a}=1.5043 \mathrm{E}-05, \mathrm{~b}=0.3754, \mathrm{c}=-0.0865, \mathrm{~d}=-0.3393 . \Delta \mathrm{p}$ is given in $(\mathrm{kPa})$ and $\mathrm{S}$ given in $(\mathrm{m})$.

The heat transfer results of swirling flow through sudden pipe expansion compared with no swirling flow through straight pipe are correlated in the form of

$\mathrm{Nu}_{\mathrm{mr}}=\mathrm{f}(\operatorname{Re}, \Theta, S)$. Figure 17 shows the experimental and empirical results for the suggested correlations of each swirl angle for the turbulent swirling flow with different vane angle values. The general empirical equation and its constancies are;

$$
N u_{m r}=a \operatorname{Re}+b(\tan \theta)+c S+d
$$

Where $\mathrm{a}=6.21773 \mathrm{E}-8, \mathrm{~b}=0.98267, \mathrm{c}=-1.1242, \mathrm{~d}=0.8338$.

The enhancement efficiency results are correlated in form of $\eta=f(\operatorname{Re}, \Theta, S)$. Figure 18 shows the experimental and empirical results for the suggested correlation of each swirl angle. The general correlation and its constants are;

$\eta=a \operatorname{Re}+b(\tan \theta)+c S+d$

where $\mathrm{a}=-6.876 \mathrm{E}-6, \mathrm{~b}=1.0206, \mathrm{c}=-1.1881, \mathrm{~d}=1.0302$.

The correlation is valid for sudden expansion ratio of $(\mathrm{d} / \mathrm{D}=0.72)$, vane angle $\left(\Theta=15^{\circ}, 30^{\circ}\right.$ and $\left.45^{\circ}\right)$, swirler location $(\mathrm{S}=10 \mathrm{H}, 20 \mathrm{H}$ and $40 \mathrm{H})$ and Reynolds number ranges from 9,000 to 41,000 within r.m.s. error of $17.5 \%, 11.93 \%$ and $18.46 \%$ for relative mean Nusselt number, pressure drop and enhancement efficiency respectively.

\section{CONCLUSIONS}

The present work provides an experimental investigation of heat transfer and pressure drop characteristics of turbulent swirling airflow through an axisymmetric sudden expansion pipe. The examined conditions include variations of Reynolds number of $R e$ $=10,000$ to $40,000, d / D=0.72$, swirler vane angle $\theta=15^{\circ}, 30^{\circ}$ and $45^{\circ}$. The swirl generator was located at three different locations $(S=10,20$ and $40 H)$ upstream and downstream of the sudden expansion. Based on the present study, the following conclusions are summarized:

1. The heat transfer rate and pressure drop increase with increase of Reynolds number and swirl angle.

2. The enhancement efficiency $(\eta)$ increases as swirl angle increases while, it decreases as Reynolds number increases leading to the conclusion that the propeller fan swirler is more effective at low Reynolds number and high swirl angle.

3. As the swirler is close to the edge of sudden expansion, for the upstream and 
downstream, the enhancement efficiency increases.

4. For upstream swirling, the experimental results indicate that inserting the propeller upstream of the tube provides considerable improvement of the heat transfer rate up to $190 \%$ for all swirler angles with higher values obtained at $\theta=45^{\circ}$. While, inserting the propeller downstream of the tube provides considerable improvement of the heat transfer rate with about $20 \%$ higher than inserting the propeller upstream the tube at swirl angle of $\theta=45^{\circ}$.

5. In general, the downstream swirler gives higher enhancement efficiency than the upstream one.

\section{REFERENCES}

[1] Huang R.F., and Tsai F.C., Observations of swirling flows behind circular disks, AIAA Journal, (2001), 39, 1106-1112.

[2] Bilen K., Bakirci K., Yapici S., and Yavuz T., Heat transfer from a plate impinging swirl jet, Int. J. Energy Res., (2002), 26, 305-320.

[3] Datta A., Influence of inlet flow conditions on the performance of a swirl-Stabilized combustor burning liquid fuel spray. Int. J. Energy Res. April 2000, 24, 373-390.

[4] Saha S.K., and Dutta A., Thermo hydraulic study of laminar swirl flow through a circular tube fitted with twisted tapes. J. Heat Transfer (2001), 123 (3) 417-427.

[5] Saha S.K, Dutta A., and Dhal S.K., Friction and heat transfer characteristics of laminar swirl flow through a circular tube fitted with regularly spaced twisted tape elements. Int. J. Heat and Mass Transfer, (2001), 44, 4211-4223.

[6] Hong S.W., and Bergles A.E., Augmentation of laminar flow heat transfer in tubes by means of twisted-tape inserts. ASME J. Heat Transfer, (1976), 98, 251-256.

[7] Yildiz C., Bicer Y., and Pehlivan D., Effect of twisted strips on heat transfer and pressure drop in heat exchangers. Energy Conversion Management, (1998), 39 (3/4) 331-336.

[8] Chang S.W., Yang T.L. and, Liou J.S., Heat transfer and pressure drop in tube with broken twisted tape insert. Experimental Thermal and Fluid Science, (2007), 32, 489-501.

[9] Eiamsa-ard S., and Promvonge P., Thermal characteristics in round tube fitted with serrated twisted tape. Applied Thermal Engineering, (2010), 30, 1673-1682.

[10] Wongcharee K., and Eiamsa-ard S., Friction and heat transfer characteristics of laminar swirl flow through the round tubes inserted with alternate clockwise and counter-clockwise twisted-tapes. International Comm., Heat and Mass Transfer, (2011), 38, 348-352.

[11] Gül H., and Evin D., Heat transfer enhancement in circular tubes using helical swirl generator insert at the entrance. International J. of Thermal Sciences, (2007), 46, 1297-1303.

[12] Zaherzadeh N.H., and Jagadisht B.S., Heat transfer in decaying swirl flows. Int. J. Heat and Mass Transfer., (1975), Vol. 18, 941-944.

[13] Saraç B.A., and Bali T., An experimental study on heat transfer and pressure drop characteristics of decaying swirl flow through a circular pipe with a vortex generator. experimental thermal and fluid science, (2007), 32, 158-165.

[14] Mostafa A.A., Effect of swirl angle and geometry on heat transfer in turbulent pipe flow. M.Sc. Thesis, (1980). Faculty of Engineering, Cairo University. 
[15] Mostafa G.M., Effect of swirling angle and swirler number on heat transfer and pressure drop in turbulent tube flow. M.Sc., (1987). Thesis, Faculty of Engineering, Cairo University.

[16] Durmus A., Kurtbaş I., Gülçimen F., and Turgut E., Investigation of the effect of co axis free rotating propeller type turbulators on the performance of heat exchanger. Int. Commun. Heat and Mass Transfer, (2004), 31, 133-142.

[17] Kurtbaş I., Durmuş A., Eren H., and Turgut E., Effect of propeller type swirl generators on the entropy generation and efficiency of heat exchangers. Int. J. Thermal Science, (2007), 46, 300-307.

[18] Eiamsa-ard S., Rattanawong S., and Promvonge P.T., Turbulent convection in round tube equipped with propeller type swirl generators. Int. Commun. Heat and Mass Transfer, (2009), 36, 357-364.

[19] Vanierschot M., and Van den Bulck E., The influence of swirl on reattachment length in an abrupt axisymmetric expansion. Int. J. of Heat and Fluid Flow, (2008), $29,75-82$.

[20] Dellenback P.A., Metzger D.E., and Neitzel G.P., Heat transfer to turbulent swirling flow through a sudden axisymmetric expansion. J. of Heat Transfer, (1987), Vol. 109, 613-620.

[21] Dellenback P.A., Metzger D.E. and Neitzel G.P., Measurement in turbulent swirling flow through an abrupt axisymmetric expansion. American Institute of Aeronautics and Astronautics, (1988), 26 (6), 669-681.

[22] Zohir A.E., Abdel Aziz A.A., and Habib M.A., Heat transfer characteristics in a sudden expansion pipe equipped with swirl generator", Int. J. of Heat and Fluid Flow, (2011), 32, 352-361.

[23] Khalil A., Zohir A.E., and Farid A.M., Heat transfer characteristics and friction of turbulent swirling air flow through abrupt expansion. Am. J. Sci. Ind. Res., (2010), vol. 1(2) 364-374.

[24] Baughn J.W., Hoffman M.A., Launder B.E., and Takahashi, R., Turbulent heat transport in circular ducts with circumferentially-varying heat flux. ASME Journal of Heat Transfer, (1984), Vol. 106, pp. 64-70.

[25] Incropera J. and Dewitt M., Fundamentals of heat transfer. John Wiley and Sons, (1981), Inc., New York.

[26] Holman J.P., Experimental method for engineers. Fourth Editions, (1984), McGraw-Hill Book Company, New York.

[27] Zohir A. E., Turbulent heat transfer characteristics and pressure drop in swirling flow at upstream and downstream of an abrupt expansion. Heat Mass Transfer, (2012), 48:529-539. 


\section{زيادة انتقال الحرارة خلال التمدد المفاجئ للأنابيب لسريان الهواء المضطرب بإستخدام \\ مولد دوامات مروحي \\ أزمهد علاء الدين زهير (باحث رئبسي)}

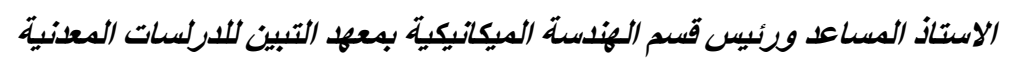

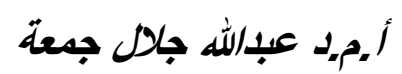

الأستاذ المساعد ورئيس قسم التبريب والتكييف بكلية التعليم الصناعي بجامعة خوان

هذا البحث يهدف لدراسة خصائص انتقال الحرارة وانخفاض الضغط لسريان الهواء المضطرب خلا التمدد المفاجئ في الأنابيب (d/D = 0.72) بداخلها مولا دوامات مروحي بزوايا ريش مختلفة. تمت الدراسة عند قيم مختلفة لرقم رينولدز تتراوح من 10000 الى 40000 تحت تأثثر فيض حراري منتظم. تم إستخدام أربع مولدات دوامية من النوع المروحي ذي خمسة ريش بزوايا 15 و30 و 45 درجة نم وضعها في المقدمة كل على حدة والرابع بزاوية 45 درجة نم وضعه بعد التمدد المفاجئ. وضع مولد الدوامات المروحي على مسافات مختلفة قبل التمدد المفاجئ هي وك وكذلك بعد التمدد المفاجئ في اتجاه السريان بنفس المسافات. أوضحت نتائج التجارب المعملية أن وضع مولد الدوامات المروحي في المقدمة بؤدي لتحسن ملحوظ في معدل

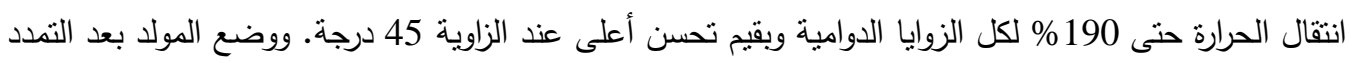
المفاجئ للأنبوبة أدى الى تحسن في انتقال الحرارة أفضل من وضع المولد في المقدمة عند الزاوية التي نم دراستها

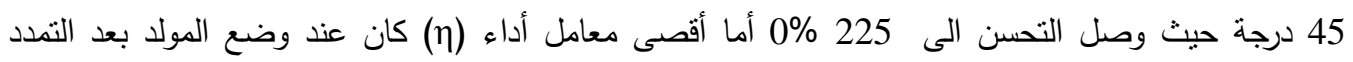
وكانت قيمته 326\% بينما كانت قيمته 213\% في حال وضع المولد في المقدمة. نم استنباط معادلات لمعامل نوسلت النسبي ومعامل الأداء كدالة في زوايا المولد وموضعه وقيم رقم رينولدز .

الباحث الرئيسي: رقم محمول 01009344305 والميل:yahoo.com) (alaa_sadegh@yahom 